\title{
FOUR-FOLD CHECK ON MEAN ANNUAL TEMPERATURE, McMURDO SOUND, ANTARCTICA
}

\author{
By Robert L. Nichols \\ (Department of Geology, Tufts University, Medford, Massachusetts, U.S.A.) \\ and Donald G. BAli \\ (Metcalf and Eddy, Engineers, Boston, Massachusetts, U.S.A.)
}

A $15 \cdot 2-\mathrm{m}$. hole was drilled in bedrock with a pneumatic drill at Marble Point, McMurdo Sound in the early part of February 1958. The temperatures at various depths in the hole were as follows (Fig. I):

$\begin{array}{cr}\begin{array}{c}\text { Depth } \\ \text { m. }\end{array} & \begin{array}{r}\text { Temperature } \\ { }^{\circ} \mathrm{C} .\end{array} \\ \text { surface } & 0 \cdot 0 \\ 3 \cdot 05 & -9 \cdot 0 \\ 6 \cdot 10 & -\mathrm{I} 6 \cdot 0 \\ 9 \cdot 10 & -\mathrm{I} 9 \cdot 0 \\ \text { I } 2 \cdot 20 & -20 \cdot 0 \\ \text { I } 5 \cdot 20 & -\mathrm{I} 9 \cdot 0\end{array}$

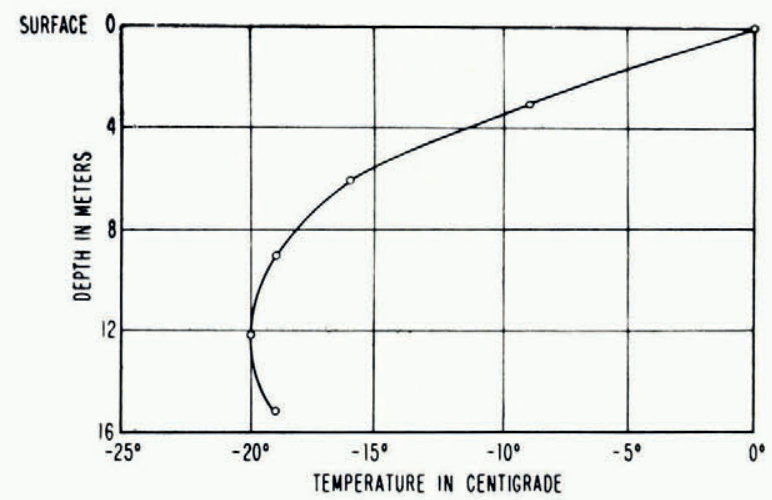

Fig. I. Curve showing the distribution of temperature in the drill hole at Marble Point, McMurdo Sound, Antarctica

The inversion of temperature between $\mathrm{I}_{2} \cdot 2$ and $\mathrm{I}_{5} \cdot 2 \mathrm{~m}$. was due to brine which entered the drill hole at $3.7 \mathrm{~m}$. and ran to the bottom (Ball and Nichols, i96o, p. r 705). The rock temperature below the zone of seasonal temperature change is in general within a few degrees of the mean annual temperature of the air just above the surface of the ground (Van Orstrand, I95 I, p. I08-o9, I I3). The mean annual air temperature at Marble Point must, therefore, be close to $-20 \cdot 0^{\circ} \mathrm{C}$.

The Wilson Piedmont Glacier is located on the west side of McMurdo Sound between New Harbour and Granite Harbour. Approximately $5 \mathrm{~km}$. inland from its terminus near Marble Point, at an altitude of about $300 \mathrm{~m}$., six test pits were dug and holes were drilled downward from the bottom of the pits by core barreling. The following temperatures were obtained from the pits and holes (Fig. 2): 


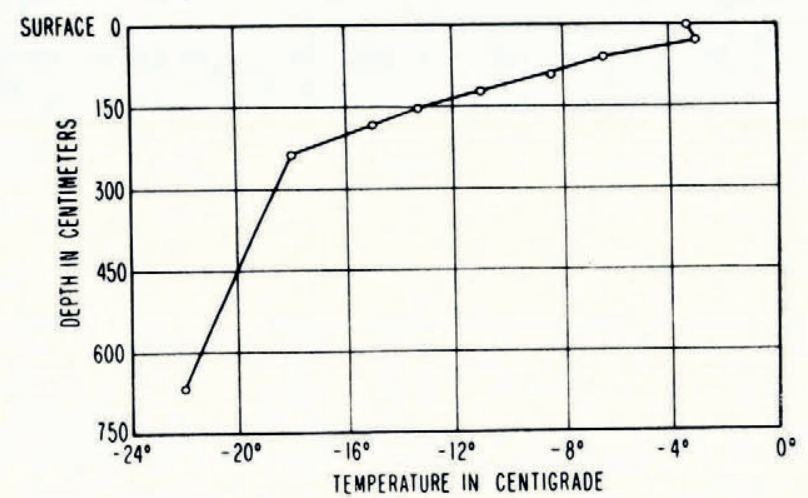

Fig. 2. Thermal gradient near the surface of the Wilson Piedmont Glacier, McMurdo Sound, Antarctica. Pit No. 4, elevation 30o m., 28 December 1957

Pit No. I

Depth
$\mathrm{cm}$.

$\begin{array}{ll}\text { surface } & -2 \cdot 2 \\ 30 \cdot 5 & -3 \cdot 0 \\ 6 \mathrm{I} \cdot \mathrm{O} & -5 \cdot 0 \\ 9 \mathrm{I} \cdot \mathrm{O} & -8 \cdot 5 \\ \mathrm{I} 22 \cdot \mathrm{O} & -9 \cdot 5 \\ \mathrm{I} 52 \cdot \mathrm{O} & -\mathrm{I} 3 \cdot 5\end{array}$

Pit No. 4

Depth
$\mathrm{cm}$.

surface

$30 \cdot 5$

$6 \mathrm{I} \cdot \mathrm{O}$

$9 \mathrm{I} \cdot \mathrm{O}$

I $22 \cdot \mathrm{O}$

$\mathrm{I} 52 \cdot \mathrm{O}$

$183 \cdot 0$

$236 \cdot 0$

$668 \cdot 0$
Pit No. 2

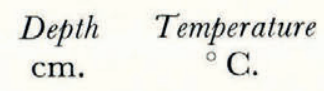

$\begin{array}{rr}\text { surface } & -2 \cdot 8 \\ 30 \cdot 5 & -4 \cdot 0 \\ 6 \mathrm{I} \cdot \mathrm{O} & -6 \cdot 5 \\ 9 \mathrm{I} \cdot \mathrm{O} & -9 \cdot 5 \\ \mathrm{I} 22 \cdot \mathrm{O} & -\mathrm{I} 2 \cdot \mathrm{O} \\ \mathrm{I} 5^{2} \cdot \mathrm{O} & -\mathrm{I} 4 \cdot 5 \\ \mathrm{I} 83 \cdot \mathrm{O} & -\mathrm{I} 6 \cdot 0 \\ 549 \cdot 0 & -2 \mathrm{I} \cdot \mathrm{O}\end{array}$

Pit No. 5

Depth Temperature

$\mathrm{cm}$. $\quad{ }^{\circ} \mathrm{C}$.

$30 \cdot 5$

$6 \mathrm{I} \cdot \mathrm{O}$

$-2 \cdot 0$

$9 \mathrm{I} \cdot \mathrm{O}$

I $22 \cdot 0$

$\mathrm{I} 83 \cdot \mathrm{O}$

$213 \cdot 0$

$579^{\circ} \mathrm{O}$

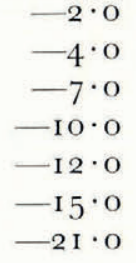

Pit No. 3

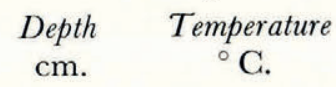

surface

$30 \cdot 5$

$6 \mathrm{I} \cdot \mathrm{O}$

$-2 \cdot 2$

$9 \mathrm{I} \cdot \mathrm{O}$

$-4 \cdot 0$

I $22 \cdot 0$

$-\mathrm{II} \cdot 7$

I $52 \cdot 0$

$-\mathrm{I} 4 \cdot \mathrm{O}$

I $83 \cdot 0$

$-16 \cdot 0$

$213 \cdot 0$

$-\mathrm{I} 6 \cdot 7$

$483 \cdot 0$

$696 \cdot 0$

$-\mathrm{I} 8 \cdot \mathrm{O}$

$-2 \mathrm{I} \cdot \mathrm{O}$

$-22 \cdot 0$

The $-22 \cdot 0^{\circ} \mathrm{C}$. at the bottom of pits Nos. 3 and 4 is not far from the mean annual air temperature in this area and when corrected for altitude gives a sea-level temperature of approximately $-20 \cdot 0^{\circ} \mathrm{C}$.

The thickness of the sea ice in McMurdo Sound close to Marble Point was determined during the $195^{8-59}$ field season. The average of 318 thickness measurements was $243 \mathrm{~cm}$. for the period 17 November to io December 1958 . They ranged from $162.6 \mathrm{~cm}$. to $27 \mathrm{I} \cdot 8 \mathrm{~cm}$. The thickest ice was along the shore where it reached the bottom. Late in the summer just 
before the ice started to move out, the thickness was about the same, but the ice was very soft and weak. The mean annual temperature necessary to form this ice can be roughly calculated. Assuming that the freezing point of the water was $-2 \cdot 0^{\circ} \mathrm{C}$., the thermal conductivity of the ice was $0 \cdot 005 \mathrm{cal} . \mathrm{cm} \cdot{ }^{-1} \mathrm{sec} .^{-10} \mathrm{C} .{ }^{-1}$, the specific heat of the ice was $0.5 \mathrm{cal} . \mathrm{g}^{-1}{ }^{\circ} \mathrm{C}^{-1}$, the water was everywhere at the freezing point, and the ice was formed in 12 months, then calculation shows (personal communication from Francis Birch) that the mean annual temperature is approximately $-\mathrm{I} 7 \cdot 0^{\circ} \mathrm{C}$. This calculation does not take into account the deterioration of the ice which takes place during the summer months. When this is considered, calculation shows that the mean annual temperature is a few degrees above $-17 \cdot 0^{\circ} \mathrm{C}$.

The mean annual air temperature at Hut Point, Cape Royds and Cape Evans, McMurdo Sound, for the 5 year interval I902, I903, I908-09, I9I I and I912 was - I $7 \cdot 4^{\circ} \mathrm{C}$. (Simpson I9I9, p. 8I). The mean annual temperature at the Williams Air Operations Facility (Hut Point), McMurdo Sound, for the 7 year interval I957-63 was $-17 \cdot 7^{\circ} \mathrm{C}$. (personal communication from William S. Weyant).

The mean annual sea-level air temperature in the McMurdo Sound area as determined from bedrock, ice pit and air temperatures, and from sea-ice thickness is, therefore, close to $-20 \cdot 0^{\circ} \mathrm{C}$.

\section{Acknowledgements}

The data were provided by the Commanding Officer, U.S. Naval Construction Battalion Reconnaissance Unit. The writers are happy to acknowledge the help they received from Commander Henry C. Stephens, U.S.N., and from Mr. J. J. Scheuren, Jr., of Metcalf and Eddy, Engineers, Boston, Massachusetts.

MS. received 3 April 1964

\section{REFERENCES}

Ball, D. G., and Nichols, R. L. 1960. Saline lakes and drill-hole brines, McMurdo Sound, Antarctica. Bulletin of the Geological Society of America, Vol. 71, No. I I, p. $1703-07$.

Simpson, G. C. 1919. British Antarctic Expedition 1910-1913. Meteorology. Vol. I. Calcutta, Thacker, Spink and Co. Van Orstrand, C. E. I951. Observed temperatures in the Earth's crust. (In Gutenberg, B., ed. Internal constitution of the Earth. Second edition. New York, Dover Publications, Inc., p. 107-49. (Physics of the Earth, Vol. 7.)) 